UDC 65.012

JEL Classification: D20

Kolesnikov E.V., Kolesnikov V.P.

\title{
EVALUATION OF LOGISTICS PROCESSES EFFECTIVENESS
}

\author{
Ukrainian State University of Chemical Technology, Dnipro, Ukraine
}

\begin{abstract}
The article discusses issues related to the optimization of logistics processes in enterprises, the problem of reducing the lost profits of commercial enterprises associated with reducing response time to an order, minimizing costs, which requires the development of new approaches to managing the order fulfillment process. The problems of organizing the management of orders of enterprises and the interaction of suppliers and consumers on the principles of logistics are necessary step in solving complex economic problems, which largely determine the relevance of the research topic, require the development of theoretical foundations and practical recommendations for managing orders in logistics processes. Solving these problems allows to increase sales and to reduce the costs of enterprises, therefore the search for internal reserves in the field of logistics processes as the most costly in the chain of creating and selling goods by optimizing costs. The logistic process becomes the leading, determining the development and success of the enterprise, and since the main requirement for the enterprise is to be as efficient as possible in its industry, the most important part of this is the need to improve the efficiency of logistics flows. In the article the organization of logistics processes and methodological approaches to the formation of performance indicators were analyzed in the context of the main components of the economic effect of the integration of logistics and marketing functions in the management of an organization. As a result, the most optimal approach to evaluating the effectiveness of logistics operations and the functioning of logistics systems was identified.
\end{abstract}

Keywords: efficiency, marketing, logistics, production, information, transporting, storage, enterprise operation.

DOI: $10.32434 / 2415-3974-2018-8-2-131-136$

\section{Introduction}

The main aim of operation of manufacturing enterprises is the working out of needed production of required quality and amount and its delivery to right place in specified time.

To cope with the task effectively it is desirable to introduce the logistic process to production system.

As we know the logistic process includes the strict sequence of actions directed on final result receiving and finished products distribution.

It consists of the acquisition of the necessary material resources, their transportation, storage of finished products, processing, receiving and delivery to the end-user.

Logistics works with material flow and it is difficult to organize and control it without its division onto definite actions, as a result the flow itself is formed.

These actions are called logistic operations.

Presentation of the main material

But the concept of logistic operation is not limited with material flows only.

For material flow control it is necessary to receive, process and give information which matches this flow. Actions performed such as technological, labor, financial and others are also related to logistic operations [1].

Thus logistic operation is the selected population of defined and consistent actions by implementation of logistic functions directed on transformation of material and related flow. The basic logistic functions are:

- Maintaining of customer service standards;

- procurement management;

- transportation;

- inventory management;

- order management;

- production management;

- pricing;

- physical distribution.

So the operation connects any of these functions with the final result.

(C) Kolesnikov E.V., Kolesnikov V.P., 2018 
Logistic operations and functions are set by initial conditions, parameters of external environment, strategy alternatives, objective function characteristics. To define the volume of firm logistic operations it should be considered the external ,interdepartmental, interparty, interoperable, internal warehouse and other cargo flows, which depends on the whole range of factors and firstly from the level of production organization. Logistic operations provide the availability of needed and qualitative item or product in right amount, right place and specified time.

List some of them: export and transportation industrial cargo, its delivery to the enterprise, loading, unloading, storage, supply to production halls, export ready semi-finished products, storage and delivery to the end-user.

Logistic operations are any operations committed with real objects and products of labor in production and circulation areas. All these operation are accompanied by information operations. Operations with information include: collection, processing and information transfer.

Types of logistic operations.

There are following logistic operations in classical concept.

By nature of flow:

- logistic operations with material flow (warehousing, transportation, equipment, loading, unloading, internal movements of raw materials at implementation of production logical functions, packing cargo, consolidation of cargo units, storage);

- logistic operations with information flow (collection, storage, processing and information transfer).

In relation to the logistics system:

- Externally oriented to integration logistics system with environment (operations in supply and sales areas);

- Internal - operations which are performed inside logistics system.

Random changes affect the external logistic operations more so then than internal ones.

By the nature of the work:

- operations with value added which change the properties of goods (cutting, packaging, drying, etc.);

- operations without value added (storage of goods).

By the transfer of ownership of the goods:

- one-sided - operations not related with transfer of ownership on production and insurance risks, which are performed inside logistic system;

- double-sided - operations related with transfer of ownership on production and insurance risks from one entity to another.

By orientation:

- direct - operations directed from material flow and information generator to its to consumer;

- reverse-operations directed from consumer to material flow and information generator.

It is necessary to note here that if goods of production-and-technical and consumer purpose return from consumer to supplier, so they don't necessary pass the same logistic chain on which they are delivered from supplier to consumer. The most common examples of reverse logistic chain distribution are: return by reseller to his goods supplier the products with the implementation deadline, buyer return to reseller the defective product, tare return by consumer to supplier etc. This is so called reverse logistics.

To logistic operations we can relate such operations as forecasting, control, operational management.

The tasks of logistics management optimization are control, analysis and reduction in distribution costs, including:

- the cost of transportation by various modes of transport;

- shipping cost at the senders, unloading at the recipients and possible transshipment en route;

- storage costs directly related to carriage due to transshipment, cargo equipment en route;

- costs dealt with cargo and goods being in transit, its unproductive storage in delivery process (interested on capital, defacement, loss, cargo theft);

- costs of formation and keeping stocks at trading companies;

- deficit costs" dealt with the lack of certain goods in some network links at separate moments, inability to manage stocks, with economic crisis;

- packaging costs, marking, paperwork, cargo insurance costs, freight forwarding costs, icebreaking costs, freight fees;

- labor costs for the amount of cargo received in shift, etc.

All the operations are performed under appropriate control.

Control of organization of unloading and receiving quality: assessment in accuracy in performing operation:

- evaluation of the nature and types of errors in the work;

- control of logistic operations management process;

- evaluation of clarity and productivity of daily work organization;

- evaluation of staff abilities in problem identification and their solving.

Acceleration on the movement of goods flows at warehouse is determined by acceleration of processing of goods and documents on all technological stages. For example, the ways of goods moving are to be straightened in horizontal and vertical direction - this leads to the reduction of 
terms of movement [2].

Dispatchers provide the operational regulation of all operations- unloading and execution of acceptance documents. Technological cards detailed description of sequence and execution methods of operations performance and list of documents compiled in the course of work and based on relevant instructions and regulations. They are intended for effective use of labor means and work force, error elimination during operation performance. They are performed into separate warehouse processing steps (acceptance, accommodation, storage, selections of goods etc.) according to functions of separate specialists or groups (brigades) of specialists-drivers of lifting machinery, selectors, packers and others. Technological processes should be clearly organized- by planning of terms and volumes of receipt and release of goods, use of working time, warehouse space and facilities. Work schedule for loading and unloading mechanisms, arrival schedules expedition schedules and others help plan the loading of people and operations performance during definite periods. Network planning using network models and schedules representing a graphic sequential image of operations with design parameters and deadlines helps to coordinate the pace of execution of various operations to get the desired result in the desired time- for example selection and packaging of large quantities of goods for loading the whole stock or marine vessel. Terms of goods movement and document flow are proportional to quantity of stock item positions and quantity of accounting operations between different structural units which are needed for tracking of goods movement and registration of necessary documentation.

As optimization tools for technological processes on warehouse we use:

- logistic audit;

- process modeling;

- business processes reengineering;

- training;

- lean technologies;

- process standardization;

- dispatch application;

- technological cards;

- network graphics;

- operational planning;

At the industrial enterprise which interacts with environment through material and energy inputs in accordance with production function performed, applied technology, realizable promotion of organization of production and etc., the conversion of incoming materials are performed. In turn the finished goods created in a result of this transformation come in environment (to markets, to partners on production cooperation, etc.). Information flows characterizing the source and it gives the direct (orders) and indirect (statistical data about demand) information which allows to predict the demand.

Integrated management of material flows promotion through enterprise which is based on decisions produced according to the results of information flows processing moving in reverse direction covers three main phases:

- purchases (supply);

- productions;

- sales (distribution).

Enterprise model can be introduced as the system of interdependent material and information parameters. The first group includes:

- inventory items;

- cash;

- labor resources;

- fixed assets.

Material values and information take part directly in logistic processes at enterprise (raw material, materials, semi-finished products, finished goods etc.). Other parameters involved in the promotion of material and informational flows (including fixed assets) form the infrastructure of these processes.

Degree of difficulty of logistic processes at the enterprise depends on its industry orientation since it is this factor predetermines the character of industrial processes applied technologies and as a consequence - assortment and volume of material supplies, variety of industrial, transport and manipulation operations, wide range of sold finished products as well as complexity of their structure.

Given the nature of industrial processes and applied technologies we can indicate:

- enterprises with hardware nature of production;

- enterprises with mounting machining nature of production;

At enterprises of first group the industrial processes are focused on the production of a wide range of finished products from narrow range of raw materials (typical example-chemical production). At enterprises of second group (for example in automotive industry) we can see the opposite situation - from a very large quantity of raw materials, materials, semi-finished products, accessories, subassemblies etc. the relatively small assortment of finished goods.

Material recourses flows arising in the enterprise can be consistent and parallel.

In some cases we can observe the opposite flows, for example, the flow arising when reusing scrap metal.

Material and information flows can be continuous rarely and discrete (more often). Continuous flows are characteristic first for the enterprises with hardware nature of production, 
implementing the «stationary» technological processes. In turn the discrete flows are characteristic for electro technical, automotive, light industry. Discrete material flows have different advance rate, whereupon the need for accumulation of corresponding stocks on their joints arises [3].

For effective management of material flows promotion the corresponding information systems based on computer engineering are needed. The base of these systems consists of computer storage media, principles of classification and coding of objects, documentation on material flows moving etc. Informational systems of material flows management should provide the uninterrupted functioning of specific business units guaranteed the required level of client service.

In informational systems intended for needs planning in materials and procurement the main informational flows initially move in direction which is opposite to direction of material flows promotion. However there is an information transmitted by material flows direction, they are the accounting indicators transferred to higher levels of enterprise management.

Task of evaluating the effectiveness of logistic processes in logistics system leads to the need to account for a large number of different indicators and criteria which characterize their logistics operation components (preparation, loading and unloading, transportation of material recourses etc.) The increasing of the efficiency of production and transport interaction in materials science processes of enterprises based on logistics principles.

Some indicators are not very variable, they relates to normative parameter group (established norms of supply and consumption of material resources, inventory standards etc.) Separate parameters can act as restriction, for example- vehicle carrying capacity, warehouse capacity, removal of sources (suppliers) of material resources etc.

In this case the efficiency of material processes should be understood as a quantitative measure defined as the degree of their aim achievement or performance of the logistic operation constituents during certain time and lowest possible costs.

Thus the main task to be solved in evaluating the effectiveness of logistic processes is the definition of private criteria (degrees of achievement their separate goals or operations). The main task of logistic processes in logistical support system (LS) is the ensuring of completeness and timeliness of needs satisfaction in material resources (MR) with rational spending of money so for evaluating of their effectiveness the following criteria and restriction may be accepted:

- degree of material recourses security which characterizes the completeness of satisfaction of the established need for material resource;
- efficiency of logistic processes which reflects the timeliness of logistics operations;

- profitability of logistic processes which allows to estimate total or specific costs of logistics operations.

The first two criteria are used to assess the achievement of the objectives of logistics processes and should provide the reasonable choice of their options (means) (delivery, storage of MR, suppliers) in accordance with the requirements for the reliability of logistics services and prevent a «situation of shortage», i. e. required security of MR in established terms and in case of critical situations- minimum time spent on resolving these situations with a given profitability.

The third criteria reflects the more essential sides of increase of economic efficiency of logistic processes and focuses on minimizing costs (total or specific), on the implementation of operations dealt with LS [4].

In general, the selected criteria should be sensitive to changes in the source data and allow to make an informed choice of options and ways to perform logistics processes (operations) in system of LS.

Implementation of the process of product distribution management requires the possibility of assessing the impact of logistic approach on the efficiency of economic processes. The main problem is the formation of a meter that would adequately reflects the contribution of logistic functions in ensuring the desired level of efficiency.

Despite the relative lack of study of the issue the analyses of special literary source allows to select a number of approaches to evaluating of logistic operations efficiency and logistics system functioning.

As the first approach we can highlight the use of efficiency evaluating of mathematical statistics apparatus. This group of methods involves the use of such indicators as: average number of applications (open orders) in system; average number of applications in queue; probability of failure in accepting applications for service (order acceptance for production); probability of zero wait; time distribution function for application staying in the system, etc. In general, the estimates obtained characterize the factors influencing on the magnitude of performance and logistics expenses. Such indicators can be used in determining of the parameters of logistics system, but they, as a rule, do not reflect the essence of "efficiency" category, i.e. do not demonstrate the ratio of "cost-result".

The second common approach involves the correlation of performance results (as a rule - profit from sales) with logistics costs (in some sources the characteristics of expenses is called the capital invested in logistics). As the characteristics of the result in given type of indicators the profit is used, 
so such indicator can be called as the profitability of logistics costs.

While using the given approach, the juxtaposition of profit obtained and costs on individual logistic operations is incorrect as the cost reduction in one of the functional areas can result in cost increase in another one. Thus it is needed to match the total logistics cost with profit (result).

The indicator obtained is the private factor indicator of efficiency, as it correlates with the activity result only the certain enterprise costs group (costs subjected to logistic optimization-logistic costs) not the total costs dealt with the production and distribution. Given indicator is suitable form application in conditions of direct logistic effect: its dynamics reflects the anticipation of growth result over the growth of the logistics costs. But when there is a marketing component in logistic effect, the use of this indicator will require the delimitation of influence of marketing and logistic function on result that will significantly complicate the use of this method.

So the most rational is the third approach which correlates the total costs on production and distribution with the system functioning result. As a gauge we can use the indicator of product profitability. Change in profitability as a result of direct reduction of logistics costs or redistribution of fixed costs (when the logistic optimization is accompanied by changes in sales), gives the clear view of efficiency dynamics.

From the standpoint of this approach we consider the formation of efficiency indicators in a cut of main components of economic effect from integration of logistic and marketing functions in management organization process (economic system).

In terms of direct logistic effect the sales revenue obtained by organization (economic system) is unchanged, as the logistics optimization does not provide the sales volume changes in kind and cost. Price of goods during the period can change, but for reasons not directly related with the organization of goods movement.

Thus, sales revenue (excluding VAT) can be determined by the formula:

$$
\mathrm{B}=\mathrm{CN},
$$

where $\mathrm{C}-$ the average price in the period under review; $\mathrm{N}-$ sales in volume terms.

The cost of products sold after logistics optimization will differ from the base case by the amount of change in logistics costs.

$$
\text { Spr=Sbaz }- \text { DZl. }
$$

Where Sbaz - cost of goods sold in the basic version of the functioning of the logistics system of the organization (before optimization); DZL - the change in the total logistics costs due to the optimization of the processes of distribution.

$$
\mathrm{DZl}=\mathrm{Zbaz}-\mathrm{ZPR} \text {, }
$$

where Zbaz, Zpr - the amount of logistic costs, respectively, for the basic and design options for the functioning of the system (only cost elements that are subject to change in the optimization process are taken into account).

Direct marketing effect leads to a change in sales in volume terms. If at the same time no marketing decisions were made to change the price (change in positioning), then the price dynamics during the period will correspond to the general price level for the goods of this group. In these conditions, the revenue from sales received by the enterprise (economic system) for the period in question, respectively, is determined by the basic and project variants by the formulas:

$$
\begin{gathered}
\text { Wbaz }=\mathrm{CNbaz} ; \\
\mathrm{REF}=\mathrm{CNpr},
\end{gathered}
$$

where Nbaz, Npr - sales in physical terms for the basic and design options; $\mathrm{C}-$ the average price in the period under review.

In the context of combining the logistic effect with the marketing direct reduction of logistic costs is accompanied by an increase in sales and the «economies of scale» that is, the optimization of the logistics process.

Predicting the impact of changes in logistics costs on the value of production costs and profitability, the company obtains the basis for planning logistics activities and adjusting the marketing strategy.

\section{Conclusions}

Thus, summing up the first chapter of the graduation qualification work, the logistic process is in a certain way organized in time sequence of logistic operations / functions, allowing to achieve the goals set for the planned period of the logistic system or its network (functional) units. Logistics audit, process modeling, business process reengineering, personnel training, lean technologies, process standardization, scheduling, flow charts, network graphs, operational planning, as well as technical tools: computer systems, radio communication systems, intrawarehouse television and other office equipment. 


\section{REFERENCES}

1. Kolesnikov, V.P. (2015). Lohistyka khimichnykh pidpryiemstv [Logistics of chemical enterprises]. Dnipro: DVNZ UDKhTU [in Ukrainian].

2. Hadzhynskyi, A.M. (2011). Osnovy lohystyky. Uchebnoe posobye [Basics of logistics. Tutorial]. Moskov, Marketynh [in Russian].

3. Vyrabov, S.A. (2010). Skladskoe i tarnoe khoziaistvo [Warehouse and tare economy]. Kyiv, Vyshcha shkola [in Ukrainian].

4. Bauersoks, D.D., Kloss, D.D. (2010). Lohystyka: yntehryrovannaia tsep postavok [Logistics: integrated supply chain]. Moskov: ZAO «OlympByznes» [in Russian].

Received 19.10.2018

Reviewer: ass. prof., ass. prof. Chupryna N.M.

\section{ОЦІНЮВАННЯ ЕФЕКТИВНОСТІ ЛОГІСТИЧНИХ ПРОЦЕСІВ}

Колесников Е.В., Колесніков В.П.

У статті розглянуті питання, пов'язані з оптимізацією логістичних процесів на підприємствах, проблема скорочення упущеної вигоди торгових підприємств, пов'язаної зі зменшенням часу реагування на замовлення, мінімізація витрат, що вимагає розробки нових підходів до управління процесом виконання замовлень. Проблеми організації управління замовленнями підприємств, взаємодії постачальників і споживачів на принципах логістики є необхідним етапом вирішення складних економічних задач, що багато в чому визначає актуальність теми дослідження, вимагає розробки теоретичних основ і практичних рекомендацій з управління замовленнями в логістичних процесах. Вирішення зазначених проблем дозволяє збільшити обсяг продажів $i$ знизити витрати підприємств, так як пошук внутрішніх резервів иляхом оптимізації витрат доцільно проводити в сфері логістичних процесів, як найбільш витратних в ланцюгу створення і реалізації товару. Логістичний процес стає провідним, який визначає розвиток і успішність функиіонування підприємства, а так як основною вимогою до підприємства є - бути максимально ефективним у своїй галузі, то найбільш важлливою частиною цього є необхідність підвищення ефективності логістичних потоків. У статті було виконано аналіз організації логістичних процесів і методичні підходи до формування показників ефективності в розрізі основних складових економічного ефекту від інтеграції функиій логістики та маркетингу в процесі управління організацією. $B$ результаті виявлено найбільш оптимальний підхід до оцінювання ефективності логістичних операцій і функціонування логістичних систем.

Ключові слова: ефективність, маркетинг, логістика, виробництво, інформація, транспортування, зберігання, робота підприємства.

\section{ОЦЕНКА ЭФФЕКТИВНОСТИ ЛОГИСТИЧЕСКИХ ПРОЦЕССОВ}

Колесников Е.В., Колесников В.П.

В статье рассмотрены вопросы, связанные с оптимизацией логистических процессов на предприятиях, проблема сокращения упущенной выгоды торговых предприятий, связанной с уменьшением времени реагирования на заказ, минимизация затрат, что требует разработки новых подходов к управлению процессом выполнения заказов. Проблемы организации управления заказами предприятий, взаимодействия поставщи ков и потребителей на принципах логистики является необходимым этапом решения сложных экономических задач, что во многом определяет актуальность темы исследования, требует разработки теоретических основ и практических рекомендаций по управлению заказами в логистических процессах. Peшение указанных проблем позволяет увеличить объем продаж и снизить затраты предприятий, так как поиск внутренних резервов путем оптимизации затрат целесообразно проводить в сфере логистических процессов, как наиболее затратных в иепочке создания и реализации товара. Логистический процесс становится ведущим, определяющим развитие и успешность функционирования предприятия, а так как основным требованием к предприятию является - быть максимально эффективным в своей отрасли, то наиболее важной частью этого является необходимость повышения эффективности логистических потоков. В статье был проведен анализ организации логистических процессов и методические подходы к формированию показателей эффективности в разрезе основных состав ляющих экономического эффекта от интеграции функций логистики и маркетинга в процессе управления организацией. В результате выявлен наиболее оптимальный подход к оиенке эффективности логистических операций и функционирования логистических систем.

Ключевые слова: эффективность, маркетинг, логистика, производство, информация, транспортировка, хранение, работа предприятия 